\title{
Sid New Disease Reports \\ First report of Synchytrium endobioticum causing potato wart in Georgia
}

\author{
L. Gorgiladze, G. Meparishvili, Z. Sikharulidze*, K. Natsarishvili and S. Meparishvili
}

Shota Rustaveli Batumi University, Institute of Phytopathology and Biodiversity, 90, str. Tavisupleba, Kobuleti, 6200, Adjara, Georgia

*E-mail: zsikharulidze@ymail.com

Received: 17 Mar 2013. Published: 07 Aug 2014. Keywords: Solanum tuberosum, quarantine pest, sporangia, PCR test, plant pathogen

Potato (Solanum tuberosum) is one of the most important food crops worldwide and it is an important component of the diet in Georgia. Diseases of potato, especially potato wart disease (PWD), are considered to be major constraints to potato production. PWD has spread throughout the world through the movement of warted tubers (Franc, 2007). The National Agency of Food Safety of Georgia lists Synchytrium endobioticum as an A2 quarantine pest.

Observations of potato plantations undertaken in different agro-ecological zones of Georgia during 2009-2013 showed that potato wart occurred only in the Khulo area, which is the most mountainous region in the Autonomous Republic of Adjara, Western Georgia. The region is considered as economically important for potato production. PWD symptoms - galls of various colours (from yellow-green to brown) - were observed on the tubers for the first time in Tabakhmela and Didajara villages in June 2009 (Fig. 1). However, the growers from these villages informed us that disease symptoms had been noted in 2006 and 2007 on potato cv. 'Agria', which is widely grown here for home consumption. According to the survey results from 2010-2012, the disease was also found in other villages of Khulo municipality (Ghorjomi, Tkhilvana Danisparauli) on varieties Agria, Finka, Picasso and Marfona. The disease symptoms were observed on the tubers, stolons and root neck. In 2013, by the end of potato growing season, the disease was also found in Diakonidzeebi village (Khulo region) and in stored potato in cellars too.

Summer and winter sporangia were observed from the galls. Winter sporangia (Fig. 2) were typical of S. endobioticum: golden-brown to darkbrown, thick-walled, spherical to ovoid in shape, with irregularly shaped

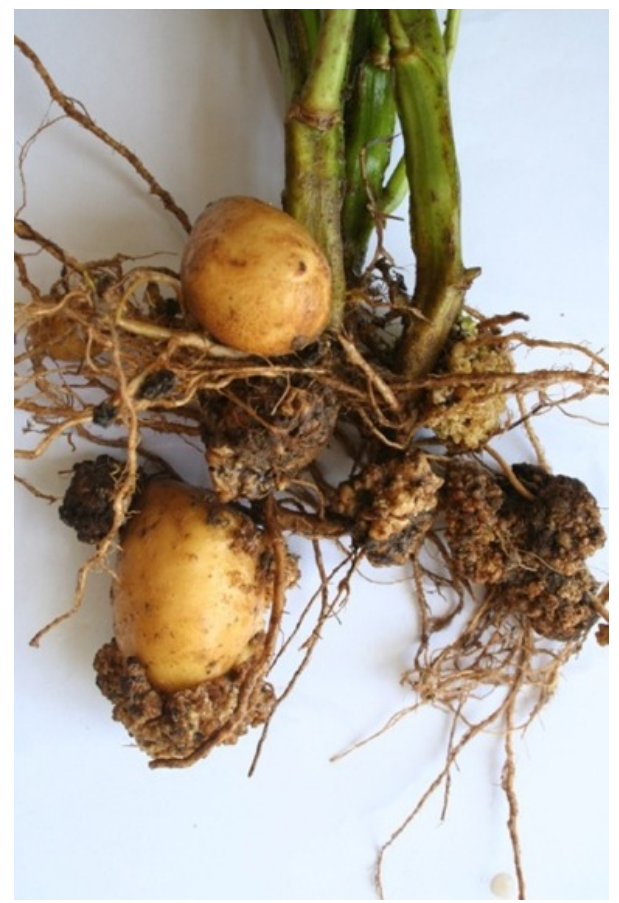

walls. All samples obtained were identified as $S$. endobioticum based on the morphological descriptions (OEPP/EPPO, 2004) and a specific PCR test using primers F49 and R502 (van den Boogert et al., 2005). Samples were also sent to the Netherlands Plant Protection Service, where the identification was confirmed. To our knowledge, this is the first report of potato wart disease caused by Synchytrium endobioticum in Georgia. The research is continuing under a $\mathrm{PhD}$ programme.

\section{Acknowledgements}

The study was supported by projects G-1775p and 31/73. We thank Dr. R. Thwaites (FERA, UK) and Dr.G. van Leeuwen (the Netherlands) for assistance.

\section{References}

Franc G, 2007. Potato Wart. APS Features.

https://www.apsnet.org/publications/apsnetfeatures/Pages/PotatoWart.aspx http://dx.doi.org/10.1094/APSnetFeature-2007-0607

OEPP/EPPO. 2004. Diagnostic protocols of regulated pests. OEPP/EPPO Bulletin. 34, 213-218

Van den Boogert PHJF, van-Gent-Pelzer MPE, Bonants PJM, De Boer SH, Wander JGN, Lévesque CA, van Leeuwen GCM, Baayen RP, 2005. Development of PCR-based detection methods for the quarantine phytopathogen Synchytrium endobioticum, causal agent of potato wart disease. European Journal of Plant Pathology 113, 47-57. http://dx.doi.org/10.1007/s10658-005-0297-x

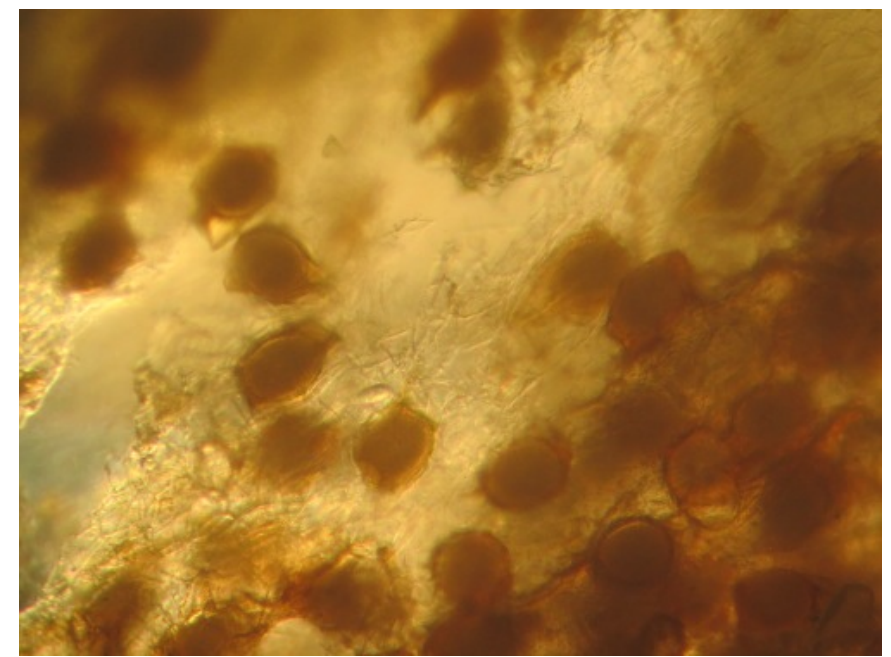

Figure 2

Figure 1

To cite this report: Gorgiladze L, Meparishvili G, Sikharulidze Z, Natsarishvili K, Meparishvili S, 2014. First report of Synchytrium endobioticum causing potato wart in Georgia. New Disease Reports 30, 4. http://dx.doi.org/10.5197/j.2044-0588.2014.030.004 (c) 2014 The Authors

This report was published on-line at www.ndrs.org uk where high quality versions of the figures can be found. 